\title{
First Language Acquisition in Informal Macro Setting
}

\author{
MarziyehNekoueizadeh ${ }^{1}$, Firooz Sadighi ${ }^{2}$, Maral Azizi $^{3}$ \\ ${ }^{I}$ Department of English Language, Marvdasht Branch, Islamic Azad University, Marvdasht, Iran. \\ ${ }^{2}$ Department of English Language, Shiraz Branch, Islamic Azad University, Shiraz, Iran. \\ ${ }^{3}$ Department of English Language, Shiraz Branch, Islamic Azad University, Shiraz, Iran.
}

\begin{abstract}
Macro-setting is perceived to have a great potentiality for first language acquisition. Informal macro-setting is believed to provide unconsciously and incidentally acquisition opportunities through exposure to the texts such as books, magazines or authentic language input through technology which give rise to learner's outcomes. Fortunately, the significance of informal macro-setting is mostly respected and overestimated in most nations, especially in developing countries that children have limited social interaction with their parents or siblings. Thus, this paper is a step towards investigating electronic and non-electronic means in respect to improve informal macro-setting as an indirect social context as essential trigger for communicative experience, which motivate process in first language acquisition.
\end{abstract}

Keywords: First Language Acquisition, Macro-setting Informal setting, Technology

\section{Introduction}

In the last two decades, technologyhasbecome more portable, affordable, effective and easy to use by sharing and showing a variety of programs to both instruct and entertain children in three basic audiovisual mass media technologies mode: text, audio and video. The impressive developments in audio, video, and computer-mediated communication programs offer many possibilities for children to acquire first language via listening and watching TV and radio programs, watching videos, and holding conversations in real-time. With advances in technology such as larger screens that provide images in high definition, three-dimensional surround sound, and greater possibilities for interaction, the power of media will likely only increase for the foreseeable future (Kirkorian, Wartella, \& Anderson, 2008).Based on Input hypothesis (Krashen, 1985) language input for FLA is necessary by indicating that learners are interested in comprehensible input "i+1" in communicative setting (Hatch, 1987; Long, 1985 and Mead, 1934). Through engagement in multimedia, children expose to world of raw input in which an interaction among children's mental abilities, linguistic environment,and the auditory and visual environment is happened subconsciously by using strategies for comprehension and confirmation checks to promote language acquisition. The proposal is that it is the interactional modifications made upon raw input to make it comprehensible which serves to facilitate language acquisition. The multimedia language learning environment may provide the ideal facility with which both to provide language input and accompany this with a range of support features which can be used to assist comprehension. In fact, multimedia-delivered language acquisition environment is designed to facilitate autonomous language acquisition in informal setting in which children become self-directed i.e. they are motivated to use strategies to acquire language (Eliss, 1992). The concepts of negotiation of meaning (Pica, 1993), noticing (schmidth, 1990), motivation (Crookes\&Schmidt, 1991) and learner autonomy (Dickenson, 1987) provide a brief insight into how FLA might overlap with multimedia.

Informal language acquisition may be supposed as unstructured and unperposeful but it has important and extensive role in first language acquisition. In fact, language input in informal setting remains a vast and largely impact on language acquisition. Technology provides an informal environment for children to acquire L1. In which, Individual child can find a context using his/her mother tongue and observes, listens and participates in the communication as a source of language input to acquire first language as that she/he does every day in his/her life.

Based on previous studies, the initial language development takes place within the home-grown as informal setting. As such, the quality of the macro informal setting is an important influence on the first language development so, the current research on the importance of informal setting points to the years of prekindergarten as the sensitive period for first language acquisition.

Macro Informal setting neither came naturally nor is developed automatically, therefore it is necessary to include the education of the family in any effective early childhood development program.Hence, the first part of this paper gives some background information about analyzing the macro and micro contexts and forces in which language acquisition is embedded. Secondly, the authors explore the challenges of language acquisition in the cases studied and literature. Finally, the authors propose some possible ways of improving informal setting context. 


\section{Literature Review}

Knowles in his work Informal Adult Education (1950) introduced informal language learning for the first time. Then in 1974 Coombs and Ahmed defined it as the lifelong process by which every individual acquires and gathers knowledge, skills, attitudes and insights from exposure to the environment at home or at work through reading newspapers and books or by listening to the radio, viewing films and television. According to Cross's (2006) definition of informal education; it is unorganized, unsystematic and even unintentional at times. On the other hand, Marsick and Watkins (1990) define formal learning as classroombased, highly structured and intentional. Lightbown and Spada (2001) describe informal setting as the contexts in which the adult learner is exposed to the target language at home, at work, or in social interaction, but formal settings as the contexts where the target language is being taught to a group of second or foreign language learners. Some other similar definitions of formal and informal learning also exist (Merriam, Caffarella\& Baumgartner, 2007). As a whole, in the formal language learning setting the focus of learning is on the language itself but in informal language learning setting is on meaning (Rogers, 2004). Every child can learn his or her first language successfully in just few years without the need for formal lessons. A lot of researches related to the present study consider the use of technology to facilitate language learning (Adams, Morrison, \& Reedy, 1968; Decker, 1976; Keller, 1987; Clark \&Sugrue, 1991; Phillips, 1998; Hubbard, 1998; Clifford, 1998; Egan, 1999; Pemberton et al, 2004).

Based on the employment of the behaviorist theory to the use of technology in informal language learning setting, Rogers (2004) claims that the behaviorists have worked well in explicit teaching and computerassisted instruction (e.g. learning through repetitions, drills and practice) but they would not be suitable for learning informally from exposure to audio/visual mass media. Moreover basedon thebehaviorist approach, language learners need to do some exercises and drills and follow some pre-designed activities even in informal settings. In the continuum development of language study, the cognitive developmental process, defined by Piaget (1936), Bruner (1966) and Ausubel (1963), is as those mental processes that cannot be observed through human beings' problem solving process and learning strategies. They believe that a human being possesses intrinsic modes of receiving, processing and utilizing information at different cognitive development stages. In education, cognitive developmental theory is to develop students' ability of creative thinking, information analyzing, and problem-solving through computer-assisted instruction. According to the constructionist view, the acquisition of language can happen through exposure to authentic language input in informal settings (Pemberton et al., 2004). Various audiovisual programs like TV can be used as authentic sources of language input in informal settings. The study of Pemberton et al. (2004) supported the constructionist approach through the use of subtitle which provides comprehensible input. The participants of the study were given a language learning version of subtitles that provide extra language support, which could help language learners to understand more from their viewing. Nunan (1999) defined authentic language materials as spoken or written language material that has been produced in the course of real communication and not specifically produced for the very purpose of language teaching. Since 1970s, researchers have been interested in the applicability of different authentic programs such as news, movies, songs, and cartoons as satellite or conventional TV programs that provide the necessary language input for first and second language acquisition. According to Bandura's (1977) social learning theory, learning is a cognitive process. It takes place in a social context through observation and modeling. Based on the observations we get information regarding the observed behavior, and then make decisions based on that information. Vygotsky suggests a social constructivist theory which gives special attention to one's social and cultural backgrounds to determine one's behavior. He believed that human's growth is a product of culture. The influence of constructivist theory on the development and implementation of educational technology is mostly reflected in the pioneering educational games, multimedia development and dynamic online interactions.

The role of input in acquiring first language is not deniable. Language input is an important factor in both first and second language acquisition process. According to Krashen's (1981) input hypothesis, language learners must receive comprehensible input which contains language structures that are beyond their current level (I+1). According to him, language acquisition can take place in informal setting if language learners are indirectly involved in intensive exposure to language input.The interaction between the peers is a source of language input for informal learning when the focus is on the meaning rather than the form of the language. One of the authentic sources of language input in which learners acquire the language informally is the social interaction. It has been emphasized by Long's (1996) Interaction Hypothesis in which conversational interaction enhances language acquisition. Accordingly, negotiation of meaning which triggers interactional adjustments can contribute to language acquisition. According to Vygotsky (1978), interactions promote learning. In brief, language learning in informal setting include learners' interaction with native or non-native speakers in the target language country or a country where English is the second language. Besides, another example of language learning in informal settings is learners' use of different technologies at home or at work through watching a movie, or listening to music or song provide appropriate language input. (Lightbown\&Spada, 2001). 
Various types of audiovisual programs such as cartoons, movies, songs, and documentaries have proved to be effective in increasing the motivation of the language learners. It is also believed that these types of programs are rich sources of authentic language input. The motivating aspects of learning with computers are widely praised, and there is an extremely large literature dealing with this issue (see for example, ArmourThomas, White\& Boehm, 1987; Brown, 1986; Chapelle\&Jamieson, 1986; Fox, 1988; Hicken, Sullivan\&Klein, 1992; Kinzie, Sullivan\&Berdel, 1988; Mosley, 1984, January; Perez\& White, 1985; Peterson \& Sellers, 1992, October; Pollock\& Sullivan, 1990; Relan, 1992; Waldrop, 1984; Williams, 1993; Wu, 1992). The most frequently-cited motivating aspects of computer-assisted instruction include (a) the novelty of working with a new medium (Fox, 1988), (b) the individualized nature of computer-assisted instruction (Relan, 1992), (c) the opportunities for learner control (Hicken, et al., 1992; Kinzie, et al., 1988; Pollock \&Sullivan, 1990; Williams, 1993), and (d) the opportunities for rapid, frequent non-judgmental feedback (Armour-Thomas, et al., 1987; Waldrop, 1984; Wu, 1992).

New technologies have accelerated the communication of information (Black, 2009; Smythe\& Neufeld, 2010). According to an article in the Los Angeles Times about social media in the lives of children, technology may act as a way for children to develop and keep emotional bonds with peers, as well as making their own identity. Whether children understand it or not, browsing social media sites is exposing them to different kinds of skills, such as online communication, high speed typing, and searching. Social media allows these children to be just as technology proficient as their more wealthy counterparts. While watching, for example, a movie or listening to a song, language learners indirectly take part in the language learning process when they try to understand the movie or the song by using different language learning strategies (Pemberton, Fallahkhair\&Mosthoff, 2004).Mostly, learners experience a wide range of technologies at very early age at home and by the nursery age develop their digital skills that enable them to participate in technology-driven activities as soon as they start school (Battro, 2004; Facer et al., 2003). Recently, the use of "non-desktop" technologies such as audiovisual mass media, for example, TV is also gaining interest among researchers in informal, adult and lifelong learning and second language acquisition (Milton, 2002; Evans, 2006; Mackenzie, 1997; Pemberton et al, 2004; Poon, 1992; Becker, 1996). Milton (2002) added that mass media technologies can provide teachers and learners a large amount of activities and experiences that can support language learning in informal settings as well as the formal settings of the school. Watching different programs, for example, on TV is a kind of activity in informal settings which can lead to language learning without paying attention to the fact that the focus is not on learning (Milton, 2002). It is assumed that language learners learn the language without directly getting involved in any sort of explicit language learning activities. Technology has been used for all kinds of specific language learning activities, such as oral practice and reading and writing skills development(Beckett \& Miller, 2006).

Saloman(1979)suggested Symbol System Theory for demonstrating the different media influences on learning. Saloman as an educational psychologist thinks that different media symbol system influences media information delivery and learning effectiveness. The most important part of the symbol systems theory is that effective learning through media depends on the degree of matching between the symbol systems and learners' learning contents and activities. Symbol System Theory has prepared a theoretical basis for the development and application of multimedia computation and determines how people get knowledge and access to what and how much information.If media has no symbol system; it is the same as having no numeric numbers in mathematics (Moore \& Hall, 2009). In general, media can significantly improve instruction and learning only when the media designing and information coding can deal with people's learning needs and can also be suitable for instructional contents and learners' accepting abilities. According to Mead the ability to be the other while self is himself makes the symbol important and meaningful (Mead, 1922,). It is concluded that self needs to take the attitude of both self and other at the same time. Later Mead notes that "if there is to be communication as such the symbol has to mean the same thing to all individuals involved" (Mead, 1934). Consequently, with regard to the lack of study in first language acquisition, this paper tries to investigate electronic and non-electronic means by improving informal macro-setting as an indirect social context as essential trigger for communicative experience, which can motivate process in first language acquisition.

\section{Mass Media and Informal Setting as Source of Input for FLA}

First language acquisition is to take place in informal context, children expose and access to a sort of language input that the focus is on meaning. In fact, nowadays first language acquisition simply cannot take place only through the interaction between child and his/her family without considering having exposure to some sort of language technology input. In other words, different audiovisual mass media technologies are available in informal contexts that lead to language acquisition through exposing to input via different media such as: listening and looking books and pictures; listening and watching TV; listening to music or song just as an entertainment; and playing and entreating computer games. Informal setting is also called natural language acquisition context in which the children pick up language input in the environment where it is used to interact. 
Informal setting obviously provides contextual clues for comprehending the language and facilitates understanding the rules in different physical and social contexts.

Of course, through rapid growth of informal setting input and advancements in technology and the more frequent use of the Internet, satellite, and electronic means, the opportunities for first language acquisition have greatly improved particularly in especially in developing countries. In every corner of the world, young children are acquiring languages at informal contexts through exposing to input via different audiovisual mass media technologies, which source of language input would have a greater impact on language acquisition because children have more opportunities to gain input to acquire language. In other words, first language acquisition takes place through exposing to input before it becomes mental processes for the individual language is placed in meaningful contexts. So, children have subconsciously more control over their language acquisition through opportunities in which language is meaningfully appeared.Internet technology, by its very nature, provides a vast input in authentic situation for children to construct their language through sensing the world in informal setting to use it later.Interment technology input promotes active learning through more taskoriented and content-oriented by break down the social and mental barriers than face-to- face interaction between child and his/her family. In fact, audio, video, and computer-mediated communications programs can be considered as more capable adults or peers, that pave the way for children to independently problem solving and performance through interaction in informal setting.

Another support and reason to suppose that a multimedia environment may engage in such authentic language materials and add learning value can be derived from second language acquisition (SLA) research, and theory (Doughty, 1991, Mead 1934) and learnerautonomy (Dickenson, 1987).Schmidt and Frota (1986) as cognitivists focused on the key role of "attention" that learner consciously notice the nature of language input to which they are exposed especially to appealing features of multimedia enthusiastically. On the other hand, directed attention may motivate children (crooke\& Schmidt, 1991) to attend to the color input and consequently understand features of the input by using their metacognitive strategies in the multimedia environment because such informal setting supports motivates learners to attend to the input more than other learning tools.Multimedia by juxtaposing written texts, pictures, sound and video create an environment in which children can implicitly elicit communicative language when they try to understand the movie or the song. The vast repositories of multimedia provide an interactive environment for children are very different in terms of their needs, interests, strengths and weaknesses that lead them to autonomy.

\section{Mass-mediaTechnologies}

Among environmental factors that affect language acquisition such as: family, peers and other media, the effect of communication media on children language acquisition is undeniable because many communications and interactions today are done through media. It should be quite obviously to anyone that living in a technology acre and availability to computer-mediated audio communication (CMAC) have brought dramatic impact on first language acquisition. Exposure condition to broadcasted programs on TV or radio, Internet, journal and newspapers and many subscribed satellite channels which offer abundant opportunities of easy access to language plays a crucial role for familiarizing children and motivating them to language acquisition.Moreover, millions of children throughout the world have access to different application of technology in informal language settings such as: mobile phones, PDAs, laptops and tablet PCs that their growth in the field of language acquisition and rapid transforming the language acquisition process is really unbelievable. Children get engaged in language acquisition through ideally language input naturally and truly authentic contexts occurring in the environment around children in informal setting. The multimedia communications programs provide the ideal facility to access language input with a range of support features which can be used to assist comprehension. Language input for FLA is necessary and its debate has centered on what type of input and in which setting informal or formal may best facilitate acquisition. Language acquisition is one of the dimensions of human development as a mean to communicate with others.Language acquisition is influenced by many factors such as environment and biological factor grows.Different media including television, radio, books, $\mathrm{CD}$, computers, etc. play an important role in the language acquisition of children as well as children living environment as environmental stimuli that cannot be overlooked in technology acre that are:

1. Print media: comic book, tuition books, story book, educational assistance.

2. Audio media : radio and voice recorder (film school)

3. Audiovisual media (visual auditor) : TV, computer, video and CD

4. Mobile media: Personal digital assistant (PDA), smart phones, mobile phones, personal laptops and notebooks

\subsection{Print Media:}


Print Media as an illustrated textbook plays an important role in the field of language development. The importance of educational media is to the extent that we can say almost without print media language development is not being done. Researches show that reading printed media to children even at a very young age plays as important role in the language development of children especially vocabulary and sentence structure.

According to the national center health of America, the largest language growth has been occurred from birth to age 3. In fact due to the rapid growth of the brain of infants up to 6 month, the original sound of their native language can understand. So according to scientific research council of children, reading books for children even before they can identify letters lead language development, including vocabulary development at later age.

Print and Pictorial books have several types:

\subsubsection{Comic Books:}

Children reactions' to pictorial books depend on to their age and experience. The first action of children to comic books basically is physically. For example, when the children touchthe size, shape, tissue and different parts of an unknown book, they may take that book to their mouth or turn the up side down. Under the guidance of adults, children pay special attention to content of images to make a relation between image and concepts to their communicating meanings. Soon the child considers that book has a story. When the child's understanding of time to grow, the link between the past, present, and future will be detected in the image and text and predicted that each story has beginning, middle and end. After a while their experience is more of everyday life, Children assess every book based on their own viewpoint of reality, feelings and attitudes.

\subsubsection{Toy Books:}

Many toy books include cardboard toys and pop-up books. Tap animated books, fabric books and plastic books help children to get more experience and understand their environment by their involving in $3 \mathrm{D}$ space story. So, their lexical treasury, ability to count and color detection will be strengthened to interact with adults. This group of books are valuable because cognitive language development, , recognition and social development of pre-school children will be accelerated. As well as, children gain experiences and sweet memories from these books that remain until they become older adults.

\subsubsection{Alphabet Books}

For many years, alphabet books are used for young children to recognize familiar objects, letters and sounds in order to strength their visual and verbal skills. Poupular image objects are used for young children to identifiy objects in alphabet books that they have not no more than a common name. The main objective of these alphabet books is easily to identify letters and sounds based on their related images. It should be placed several images on any screen paper of these alphabet books that kids use them independently because children can not identify the relationship between letter and sound.

\subsubsection{Number Books}

Number books like alphabet books are particularly used for educational purpose. The aim of number books is that children can relate two equal things together and count from one to ten in sequence. Good number book is usualy provided in way that a large number of word and object(s) is showing up on one page or two pages on opposite sides. A simple number book for small children is "My First Count Number" written by Eric Carel is designed in such a way that children can match numbers in squares with related image. Number books for little kids strength language development and enable them in making relation with text through reinforcing visual skills and the ability to count.

\subsubsection{Conceptual Books}

Many books that are recommended for children's cognitive development are conceptual books. These books are get involved children in undrestanding concepts based on picture. In fact, these books help children to comprehend concepts that they are more abstract and difficult for children to undrestand like prepositions or antonyms.

\subsubsection{Books Without Words}

These books explain the story lonley based on pictures. In real, children based on their creative thinking and visual litreracy underestand the meaning of actions while watching these books. By this way, childern's speaking skill will be improved by making story for thses books.

\subsection{Audio Media:}


Audio media is convenient and cost-effective technology thatstimulates our imaginations to work as a creative and active audience in the story we're hearing.

\subsubsection{Radio and Recording Audio Media}

These media,working in speech-based and music in all genres, play an increasingly positive role as media in language acquisition because oral skills (listening and talking) keep children in track of language acquisition goals. Radio plays an important role in child language acquisition. Radio in variety of interactive language, including interviews with ordinary people, is especially strengthen children's oral and listening comprehension skills.Radio as media plays a role in supporting the informal language acquisition through talk shows, reports, music and game shows.

\subsection{Audio-Visual-Media:}

\subsubsection{TV}

"Non-desktop" technologies such as audiovisual mass media, for example, TV is more efficient for children to access than other media in providing large quantities of data. Contrary to media outlets, TV can provide audio pronunciation of the language that not limited to the flow of communication to acquire the language. Huston and Wright (1983) proposed a somewhat different theory of attention to television, positing that the features of television that drive children's attention may change as a child ages. Specifically, they claimed that in infancy, perceptually salient features of television such as movement and sound effects drive attention. With age and experience, however, children are less influenced by perceptual salience and able to pay greater attention to informative features such as dialogue and narrative. Children by watching TV movies are familiar with their mother language and non-verbal gestures to observe and can be applied by displaying the daily movements of some of the concepts taught to children for example by displaying the correct etiquette, greeting, greets the two sides to be taught to children. Based on a recent survey of parents, the Kaiser Family Foundation estimated that 61 percent of children under age two use screen media (television, videos, DVDs) on a typical day and 43 percent of infants and toddlers watch television every day( Rideout\&Hamel,2006). TV programs including cartoons, movies, sitcoms, game shows, music, news, talk shows and advertisement are daily boosted the chance of reinforcing and strengthening language acquisition informally and implicitly in in the social milieu.

\subsubsection{Computers}

Computersas a type of ubiquitous and usefulness desktop technology at homes provide high face validity input, repeatedly.

\subsubsection{CD}

CD provides a large quantity of instantly accessible repeated data in informal learning settings which are believed by the behaviorist theory of learning to boost language acquisition. It is also seen more attractive than traditional books due to the very appealing features. One experiment found that children younger than two learned vocabulary better from real-life experiences than from equivalent video presentations.

\subsection{Mobile Media}

Learning via mobile media caused a large learning developments is introduced nearly 2000. Mobile as a means of learning media has this potentiality to be moved along with the Learner that reduces learning location restriction.Mobile media is a form of media that can be accessed through wireless devices such as: mobile phones, handheld computers, IPod, laptops and digital cameras. Mobile media devices are important in the sense that access to learning materials are possible in any place.

In general, mobile devices can be placed in the following four major categories: Personal digital assistant (PDA), smart phones, mobile phones, personal laptops and notebooks.

\subsubsection{Personal Digital Assistant (PDA):}

PDA is tiny or palm-sized wallet having the operating system and special software that is used to personal planning, writing notes, settings programs, read e-books, listening to music, reading and writing emails and more other operations.

\subsubsection{Smartphone:}

Smart phones are the combination capabilities of mobile phones and PDA's that their size is smaller than the PDA and bigger than mobile.

\subsubsection{Mobile:}

It can be used mainly for voice communication, sending and receiving text messages. This advanced tool can be used to connect to the Internet via (WAP) or (GPRS).Mobile phone provides learning context that learner is free about what, how and where and when to learn in which learner is in the center of learning, actively be involved in new ways of learning through interactive games or entertainment in graphics and multimedia elements that based on learner's need.

\subsubsection{Personal laptops and Notebooks:}


Notebooks and modern laptops are equipped with wireless network card, Bluetooth, infrared port Processing power, memory, operating system and screen resolution that allow the use of multimedia content. Their major weaknesses are their less mobility than other mobile devices.

\section{Discussion}

The World Wide Web was boosted in 1992 reaching the general public by 1993, opening up new opportunities language acquisition in multimedia components. However, recent advances in technology and internet bandwidth provide particularly rich contexts for L1 acquisition with opportunities for L1 input, interaction and output along with the possibility for focus on L1 form and meaning. In recent years, computer technology, particularly the internet, as an authentic language input context has begun to play an important role in enhancing language acquisition. The reason for the increase in children interest in audio, video, and computer-mediated communications programs, technology use, refers to fast pace technological changes in recent years to instruct and entertain the audience.

Multimedia can facilitate language acquisition by creating an integrative and authentic communicative environment indirectly in which children construct their interpretation.In fact, the remarkable developments in audiovisual and computer-mediated communication programs provided learn the language in both formal and informal learning settings through a number of repetition and drills which are believed by the behaviorist theory of learning to boost language learning. On the other hand, Egan (2005) developed a computer-based software program requiring the language learners to get engaged in language learning through doing some exercises such as filling the blanks, choosing the correct answers, practicing in reading and listening to authentic written and spoken language, producing language by repeating words or sentences, recording their responses and comparing them to native models (Egan, 1999).Although Egan's software leads language learners to produce speeches through interaction with the computer, the interaction is based on stimulus and response which reflect the behaviorist approach. Language learners seem to be in charge of their learning which replicates the constructive approach but the authentic language input which is offered to them and what they can gain is limited to what the software offers. This limitation may break the interaction when the software lacks the necessary stored data for that differ from the formal language used in their broader social world.

Schmidt and Frota (1986) as cognitivists focused on the key role of "attention" that learner consciously notice the nature of language input to which they are exposed especially to appealing features of multimedia enthusiastically. Although children are active viewers of television by preschool age, although the underlying mechanisms driving attention to video appear to be the same in adults and infants as young as three months, some research has found differences in the ways in which younger and older viewers watch professionally produced video.On the other hand, directed attention may motivate children ( crooke\& Schmidt, 1991) to attend to the color input and consequently understand features of the input by using their metacognitive strategies in the multimedia environment because such informal setting supports motivates learners to attend to the input more than other learning tools.

With constructivism, technology brings about changes in the first language acquisition by engaging children as active participant in a task in which they "construct" new knowledge based on experience in order to incorporate new input into their already-established schema knowledge on their own with natural language in natural setting. In fact, based on whole language theory, first or second language acquirer moves from the whole to the part by stressing on fluency over accuracy to take risk in using language pragmatically to support sociocultural theory that acquisition is a process of becoming part of a desired community.

Integrating of multimedia mass into children life provides an informal macro setting that children actively absorb, negotiate meaning, and assimilate new input through exposing to larger and better quantity of communication in which themselves interpret new information on their own terms that lead to raise their selfesteem. Using technology through multimedia promote children's motivation to develop their speaking ability linked to "communicative competence" not only ability to engage in meaningful interaction but also make more authentic communication by facial expressions and body movements by orient their social and cultural knowledge to any given context. Multimedia components give a new role to children in personalizing information that means children control the context of language acquisition by making choice in what and how to learn, skipping unnecessary input, and control over where content is appeared such as stories; cartoons; video clips; listening clips; puzzles; pictures; texts; images; chats; etc. Thus, children gain significant proficiency in language skills especially speaking and listening and to some extent in reading and writing skills in fantasy realworld context that is not directly language-oriented through self-directed and independent informal macrosetting context.

\section{Conclusion}


This research study has been concluded that there is a positive connection among macro informal setting and first language acquisition that is conducive to language developmental outcomes. In nutshell, macro informal setting, as a communication context that children expose to it via various media, extends the learning process well beyond the traditional four walls, because it is an accessible and effective set that foster a fascinating and authentic language acquisition. Children had better social skills and few behavior problems when initial language development takes place in preschool through saturated macro informal setting rather than academically focused in four levels: (1) providing positive cognitive language development; (2) designing supportive and engaging environments; (3) infusion social and emotional awareness and skills, often in short, implicit exposure, and (4) developing individualized autonomy. In this regard, the applicability ideal informal setting will endorse children in the following characteristics:

- Discover their own style of language learning;

- $\quad$ Organize the language input they receive via different mass-media (linguistic knowledge);

- Creative and use what they learn in informal setting;

- Seek occasions to use language and monitor themselves in social context (interaction skills);

- Apply strategies to comprehend the exposed language and compensate their breakdowns in real communications;

- Use memo- techniques (formulaic expressions, word collocations, rhythm, etc.) as oral production techniques

- $\quad$ Reflective to improve their communicative competence to communicate appropriately within a particular language community;

- Etc.

\section{References}

[1]. Relan, Motivational strategies in computer-based instruction: Some lessons from theories and models of motivation, in proceedings of selected research and development presentations at the Convention of the Association for Educational Communications and Technology Washington, DC, 1992.

[2]. M. Battro, Digital skills, globalization and education. In Globalization: Culture and education, in the new millennium M. SuárezOrozco, D. Baolian Qin-Hilliard, (Eds.), (California University Press: San Francisco, 2004).

[3]. A.C. Huston and J.C. Wright, Children's processing of television: The informative functions of formal features. In J. Bryant \& D.R. Anderson (Eds.), Children's understanding of television: Research on attention and comprehension (pp.35-68). New York Academic, 1983.

[4]. Adams, E., H. Morrison, \& J. Reddy, Conversation with a computer as a technique of language instruction. Modern Language Journal 52, 1968,3-16.

[5]. Baker, N, Using the TV news in the EFL classroom. Zielsprache, 26 (2), 1996, 30-33

[6]. Bandura, Social learning theory, (New York: General Learning Press, 1977).

[7]. Black, R., English-language learners, fan communities, and 21st century skills. Journal of Adolescent \& Adult Literacy, 52(8), 2009, 688-697.

[8]. Brown, J., Some motivational issues in computer-based instruction. Educational Technology, 26(4), 1986, 27-29.

[9]. Evans, Using TV news to integrate the four skills: A guide for EFL teachers. (MA TESOL Collection, 2006)

[10]. Chapelle, C., and Jamieson, J., Computer-assisted language learning as a predictor of success in acquiring English as a Second Language. TESOL Quarterly, 20, 1986, 27-46.

[11]. Clifford, R. T, Mirror, mirror, on the wall: Reflections on computer assisted language learning. Calico Journal, 16 (1), 1998 , 1-10.

[12]. Crookes, G. and Schmidt, R. W., Motivation: Reopening the Research Agenda. Language Learning, 41, 1991, 469-51

[13]. Cross, J., Informal learning: Rediscovery the natural pathways that inspire innovation and performance. (San Francisco, CA: Pfeiffer, 2006)

[14]. Ausubel, The psychology of meaningful verbal learning (New York: Grune\& Stratton, 1963).

[15]. Nunan, Second Language Teaching and Learning, (Boston: Heinle and Heinle Publishers, 1999).

[16]. Decker, H., Computer-aided instruction in French syntax. Modern Language Journal, 60, 1976, $263-273$.

[17]. Doughty, C., Instruction does make a difference: The effect of instruction on the acquisition of relativization in English as a second language. Studies in Second Language Acquisition, 13(3), 1991, 431-469.

[18]. Armour-Thomas, M. A.White, and A. Boehm, The motivational effects of types of computer feedback on children's learning and retention of relational concepts.Paper presented at the Annual Meeting of the American Educational Research Association, 1987.

[19]. Egan, K., Speaking: A Critical Skill and a Challenge. CALICO Journal, 16 (3), 1999, 277-293.

[20]. H. Beckett and P. Chamness Miller, Project-based second language and foreign language education: Past, present, future, (Greenwich, Connecticut: Information Age Publishing, 2006).

[21]. Salomon, Interaction of Media, Cognition, and Learning, (San Francisco: Jossey-Bass, 1979).

[22]. Hatch M. D, C4 photosynthesis: A unique blend of modified biochemistry, anatomy and ultrastructure, BiochimBiophysActa, 895 , 1987, 81-106.

[23]. Hicken, S., Sullivan, H., and Klein, J., Learner control modes and incentive variations in computer-delivered instruction. Educational Technology Research and Development, 40(4), 1992, 15-26.

[24]. J. Milton, Literature Review in Languages, Technology and Learning, (Report for Future Lab, 2002). Retrieved 22th June 2015 from http://www.futurelab.org.uk/resources/documents/lit_reviews/Languages_Review.pdf

[25]. J. Piaget, Origins of intelligence in the child, (London: Routledge\&Kegan Paul, 1936).

[26]. J. S. Bruner, Toward a theory of instruction, Cambridge, (Mass.: Belkapp Press, 1966).

[27]. K. Egan, An imaginative approach to teaching. San Francisco: Jossey-Bass. (Translated into Korean, Japanese, Indonesian, Spanish, 2005).

[28]. K. Facer, J. Furlong, R. Furlong, and R.Sutherland, Screenplay: Children and computing in the home, (London: RoutledgeFalmer, 2003). 
[29]. Keller, H., Pedagogical wishes for a machine dictionary: an example from Russia. MLJ, 71, 1987, 12-17.

[30]. Kinzie, M., Sullivan, H., \&Berdel, R., Learner control and achievement in science computer-assisted instruction. Journal of Educational Psychology, 80, 1988, 299-303.

[31]. Kirkorian, H. L., Wartella, E. A., and Anderson, D. R., Media and young children's learning. The Future of Children,18(1), 2008, 39-61.

[32]. L. Dickinson, Self-Instruction in language learning. Cambridge, (Cambridge University Press, 1987).

[33]. L. Pemberton, S. Fallahkhair, \& G. Masthoff, Toward a theoretical framework for informal language learning via interactive television, Paper Presented In Proceedings of IADIS International Conference of Cognition and Exploratory Learning in Digital Age,Lisbon, Portugal, 2004.

[34]. L. S Vygotsky, Mind in society, (Cambridge, MA: Harvard University Press, 1978).

[35]. M. Long, The role of the linguistic environment in second language acquisition, in W. C. Ritchie and T. K. Bhatia (Eds.), Handbook of second language acquisition, (New York: Academic Press, 1996) 413-468.

[36]. M. A.Fox, report on studies of motivation teaching and small group interaction with special reference to computers and to the teaching and learning of arithmetic. (Milton Keynes, U.K.: The Open University, Institute of Educational Technology, 1988).

[37]. M. H. Long, Bibliography of research on second language classroom processes and classroom second language acquisition. Technical report No. 2, (Honolulu: Center for Second Language Classroom Research, Social Science Research Institute, University of Hawai'i at Manoa, 1985)

[38]. M. L. Mosley, Computer-assisted instruction and continuing motivation, Paper presented at the Annual Meeting of the Association for Educational Communications and Technology, Dallas, Texas, 1984.

[39]. M. S. Knowles, Informal adult education (New York: Association Press, 1950).

[40]. Mackenzie, A. S., Using CNN news video in the efl classroom. The Internet TESL Journal, 3 (2), 1997.

[41]. Mead, G. H., A behavioristic account of the significant symbol. Journal of Philosophy, 19 (6), 1992, 157-163.

[42]. Mead, G. H., Mind, self \& society from the standpoint of a social behaviorist (Edited by C. W. Morris). (Chicago, IL: University of Chicago Press, 1934).

[43]. N. Peterson, and D. Sellers, Student motivation and learning styles in a multimedia learning environment, Paper presented at the Annual Meeting Northern Rocky Mountain Educational Research Association, Custer, South Dakota, 1992.

[44]. P. H. Coombs and M. Ahmed, Attacking rural poverty: How non-formal education can help. (Baltimore, MD: John Hopkins University Press, 1974).

[45]. P. L. Hubbard, Language teaching approaches, the evaluation of CALL software, and design implications. In W. F. Smith (Ed.), Modern media in foreign language education: Theory and implementation. (Lincolnwood, IL: National Textbook Company, 1987).

[46]. P. M. Lightbown and N. Spada, How languages are learned, Second edition, (Oxford University Press, Oxford, 2001).

[47]. Perez, E. C., and White, M. A., Student evaluation of motivational and learning attributes of microcomputer software. Journal of Computer-Based Instruction, 12(2), 1985, 39-43.

[48]. Phillips, J. K., Media for the message: Technology's role in the standards, CALICO Journal, 16 (1), 1998, 25-36.

[49]. Pollock, J., and Sullivan, H., Practice mode and learner control in computer-based instruction, Contemporary Educational Psychology, 15, 1990, 251-260.

[50]. Poon, A., Action research: A study on using TV news to improve listening proficiency, Research Report, 14, 1992, 1-70.

[51]. R. E Clark and B. M. Sugrue, Research on instructional media, 1978-1988. In G. Anglin (Ed.), Instructional Technology (Englewood Cliffs, NJ: Prentice Hall, 1991).

[52]. R. Eliss, Second language acquisition and language pedagogy. (Clevedon, UK: Multilingual Matters, 1992).

[53]. R. Schmidt, \& S. Frota, Developing basic conversational ability in a second language: A case study of an adult learner of Portuguese, in R. R. Day (Ed.), Talking to learn: Conversation in second language acquisition, (Rowley, MA: Newbury House, 1986), 237-326

[54]. Rogers, A., Looking again at non-formal and informal education - towards a new paradigm, the encyclopedia of informal education, www.infed.org/biblio/non_formal_paradigm.htm.Last updated: June 04, 2004.

[55]. S. Krashen, Second language acquisition and second language learning (Oxford: Pergamon Press, 1981).

[56]. S. B. Merriam, R. Caffarella, and L. Baumgartner, Learning in adulthood: A Comprehensive Guide. (3rd edition). (New York: Wiley, 2007).

[57]. S. D. Krashen, The input hypothesis: Issues and implications (New York: Longman, 1985).

[58]. S. Moore, and E. Hall, Review of interaction of media, cognition, and learning by Gavriel Salomon, 2009Retrieved April 12, 2009, fromhttp://novationsjournal.org/content/original_story.pl?story=6

[59]. Schmidt, R., The Role of Consciousness in Second Language Learning, Applied Linguistics, 11, 1990, 129-158.

[60]. Smythe, S., and Neufeld, P., Podcast time": Negotiating digital literacies and communities of learning in a middle years ELL classroom. Journal of Adolescent \& Adult Literacy, 53(6), 2010, 488-496.

[61]. T. Pica, Choosing and using communication tasks for second language instruction, in G. Crookes, and S. Gass (Eds.), Tasks and language learning: Integrating theory and practice (Bristol, PA: Multilingual Matters, 1993) 9-34.

[62]. V. J. Marsick and K. Watkins, Informal and incidental learning in the workplace, (London and New York: Routledge, 1990).

[63]. V. J. Rideout, and E. Hamel, The media family: Electronic media in the lives of infants, toddlers, preschoolers and their parents, (Menlo Park, CA: Kaiser Family Foundation, 2006).

[64]. Waldrop, P., Behavior reinforcement strategies for computer-assisted instruction: Programming for success. Educational Technology, 24(4), 1984, 38-41.

[65]. Williams, M., A comprehensive review of learner-control: The role of learner characteristics, Paper presented at the Convention of the Association for Educational Communications and Technology Sponsored by the Research and Theory Division, New Orleans, LA. , 1993, (ERIC Document Reproduction Service No. ED 362 211).

[66]. Wu, Y.-C., Computerized teachers' praise: Incorporating teachers' images and voices, Paper presented at the annual meeting of the Mid-South Educational Research Association, Knoxville, TN. 1992, (ERIC Document Reproduction Service No. ED 354873 ). 